\title{
Comparing the Effectiveness of Case Based Learning with Conventional Teaching in Anatomy
}

\author{
Shema K Nair ${ }^{1}$, Neha Rai ${ }^{2}$ \\ ${ }^{1}$ Professor, Department of Anatomy, LN Medical College and Research Center, Bhopal, Madhya Pradesh, ${ }^{2}$ Associate Professor, Department of Anatomy, \\ LN Medical College and Research Center, Bhopal, Madhya Pradesh, India.
}

\section{Abstract}

Introduction: Case based learning (CBL ) is an efficient method of making dry subject like anatomy interesting and student centered. Subjects and Methods: A group of students of $1^{\text {st }}$ MBBs were taught by CBL while the other group was taught by conventional teaching methods and both the groups were assessed for their performance. Results: Students had a better understanding of the topic on being taught by CBL. Conclusion: CBL is a good approach to teach anatomy to medical students as it makes the subject quite lively and clinically oriented.

Keywords: Case Based Learning, New Curriculum, Anatomy, Medical Students.

Corresponding Author: Dr. Neha Rai, Associate Professor, Department of Anatomy, LN Medical College and Research Center, Bhopal, Madhya Pradesh, India.

Received: September 2019

Accepted: September 2019

\section{Introduction}

Anatomy and dissection have been considered as a milestone in medical education. In Egypt, dissection was a religious ritual and considered as a site of passage to kingdom of dead. Towards the end of $20^{\text {th }}$ century dissection was considered as a core of teaching anatomy, defining the exact site of a lesion becomes a crucial problem for a physician and good knowledge of anatomy will definitely help in doing so. Anatomy is an important but difficult subject taught to the first year MBBS students. Sound knowledge of the subject with clear understanding of its clinical application is important to create strong foundation of sound clinical practice ${ }^{[1]}$.

Medical education has introduced numerous changes to make anatomy more interesting, and student centered. According to Albanese MA et al ${ }^{[2]}$ \& Des Marchais JE ${ }^{[3]}$, most student enjoy the active participation \& consider the process to be clinically relevant. Efforts are being made to improve the student learning by using various methodologies like case based learning (CBL), Problem based learning (PBL), etc. Benkson et al ${ }^{[4]}$ found that PBL and traditional curricula are entirely different concepts, and the two will gradually merge. CBL seems to be a more innovative method of student learning because knowledge of anatomy its application in clinical practice will definitely help us in improving our health services. Moreover CBL relies on integrated learning methods which will link anatomy with other clinical subjects making it more interesting for the student. PBL proponents argue that PBL methods encourage lifelong learning, simulate clinical practices, encourage curiosity, and create a broader understanding of the complexity of medicine ${ }^{[5,6]}$. Whereas PBL detractors argue that PBL process is time inefficient, frustrating for time pressured medical learners, and often leads to erroneous conclusions ${ }^{[7]}$.

Since anatomy is a dry and difficult subject to make it interesting, interacting, and more clinically oriented C.B.L is a very efficient method and should be incorporated in teaching anatomy.

\section{Aims \& Objectives}

1. The objectives of the study are as follows:-

2. To introduce $\mathrm{CBL}$ for $1^{\text {st }}$ year $\mathrm{MBBS}$ students in department of Anatomy.

3. To compare the effectiveness of CBL in Anatomy with conventional learning methods.

4. To access the perception of students regarding CBL.

\section{Subjects and Methods}

It is a comparative observational study designed to compare the effectiveness of C.B.L. with conventional teaching method. The study was conducted on 150 students of MBBS first year 2017 batch. Permission was taken and the study was approved by institutional ethical committee, and the head of the department.

The faculty and students were oriented and introduced to the concept of case based learning through the seminars 
Nair d Rai ; Effectiveness of Case Based Learning with Canventional Feaching in Anatomy

conducted in the department. The study was carried out in two sessions. All the students were divided into four batches A, B, C, and D consisting of 37, 38, 37 and 38 students each respectively. In the first session batches $\mathrm{A}$ and $\mathrm{B}$ were taught the topic of radial nerve through case based learning by faculty, while the other two batches $\mathrm{C}$ and $\mathrm{D}$ were taught the same topic by traditional conventional method by another faculty. After the case based teaching the batches A and $\mathrm{B}$ were given the feedback form to fill their perception regarding the CBL on the Likert scale. All the four batches were assessed in the formative assessment and the results of the batches A and B (taught by CBL) was compared with the batch $\mathrm{C}$ and $\mathrm{D}$ ( taught by conventional method) and the results were tabulated.

In the second session another topic i.e thyroid gland was taught. The batches $\mathrm{A}$ and $\mathrm{B}$ were taught this time by conventional traditional method and the batches $\mathrm{C}$ and $\mathrm{D}$ were taught the same topic by case based method. Post teaching feedback form was given to batches C and D and their perception was noted by Likert scale. In this way all the four batches got an opportunity to be taught by case based learning, and their feedbacks could be recorded. All the four batches were assessed in the formative assessment and the results of the batches $\mathrm{C}$ and $\mathrm{D}$ (taught by $\mathrm{CBL}$ ) was compared with the batch $\mathrm{A}$ and $\mathrm{B}$ (taught by non $\mathrm{CBL}$ ), and the results were tabulated.

\section{Statistics}

$\underline{\text { Mean, } S D}, p$ value and $t$ test was found. The perception of the student was also tabulated.

\section{Results}

out of the total 150 students of MBBS $1^{\text {st }}$ year only 140 submitted the feedback form as the remaining 10 students were absent. Out of 140 students 139 students agreed for CBL (score>30), and one student was in a confused state not really able to agree/disagree and none of the students were against CBL (score<20), [Table 1].

On comparing the results of the topic taught by CBL and non CBL, it was found that students taught by $\mathrm{CBL}$ performed better in their assessment. In the first session out of 10 marks students taught by CBL scored a mean of 6.46 while those taught by non CBL scored mean marks of 4.3. In the second session also students taught by $\mathrm{CBL}$ performed better than those taught by conventional method the score of mean marks out of 10 being 9.41 and 8.15 respectively.

The $\mathrm{p}$ value was found to be highly significant in both the sessions $(0.0001)-$ [Table 2]. The $t$ value shows that the difference between the two means is real and not by chance.

Table 1: Perception of Students for CBL
\begin{tabular}{|l|l|l|l|l|}
\hline S No & $\begin{array}{l}\text { Score<20 } \\
\text { Not } \\
\text { Agree } \\
\text { For CBL }\end{array}$ & $\begin{array}{l}\text { Score20-30 } \\
\text { Can't Say } \\
\text { (Agree/Disagree) }\end{array}$ & $\begin{array}{l}\text { Score>30 } \\
\text { Agree } \\
\text { For CBL }\end{array}$ & $\begin{array}{l}\text { Total } \\
\text { Students } \\
\text { Participated } \\
\text { In Study }\end{array}$ \\
\hline $\begin{array}{l}\text { no of } \\
\text { students }\end{array}$ & - & 1 & 139 & 140 \\
\hline $\begin{array}{l}\% \text { of } \\
\text { students }\end{array}$ & $0 \%$ & $0.72 \%$ & $99.28 \%$ & \\
\hline
\end{tabular}

Table 2: Comparing Results of CBL With Non CBL (Session
1 \& Session 2)

\begin{tabular}{|l|l|l|l|l|}
\hline & $\begin{array}{l}\text { CBL } \\
(\mathbf{1 - 7 5 )}\end{array}$ & $\begin{array}{l}\text { Non CBL } \\
(\mathbf{7 6 - 1 5 0 )}\end{array}$ & $\begin{array}{l}\text { Non CBL } \\
(\mathbf{1}-75)\end{array}$ & $\begin{array}{l}\text { CBL } \\
\mathbf{( 7 6 - 1 5 0 )}\end{array}$ \\
\hline MEAN & 6.46 & 4.30 & 8.15 & 9.41 \\
\hline SD & 2.22 & 3.00 & 1.42 & 0.84 \\
\hline P value & 0.0001 & 0.0001 & \\
\hline t value & 5.0196 & 6.6008 & \\
\hline
\end{tabular}

\section{Ethics}

Ethical permission was taken by ethical committee and it is attached in annexure.

\section{Discussion}

Numerous studies have been done from time to time to improve the quality of medical education, the primary motive behind all being to appraise the medical graduates and make them more competent. The present study buttresses the same motive of making medical graduates more competent.

The study was carried out to find the perception of the students regarding the case based learning. Their perception was recorded on "likert scale" ranging from 1 to 5 . The perception covered various aspects like better understanding of topic, improved self learning, application of theoretical knowledge into clinical settings, improvement in student communication skills. It also helped us to access the response of the students regarding imbibing and retaining the topic, and students were in favor of increased number of topics to be covered by CBL. [Table 1] shows an excellent response of the students in favor of CBL (99\%). Similar study was conducted by Praveen. R. Singh et al ${ }^{[1]}$ in 2011 on the students of MBBS $1^{\text {st }}$ year of Pramukhswami medical college, Karamsad ,Gujarat in which understanding of the students for CBL was observed through feedback questionnaire. A Cronbach's alpha score of 0.84 was obtained which was found to be at par with the present study. Diana Dolman's et $\mathrm{al}^{[8]}$ had a similar conclusion where I student's found a similar perception of retention of knowledge after being taught by CBL. It also rejuvenates the subject and leads to a better clinical orientation. David vernom $^{[9]}$ in his Meta analysis showed the superiority of PBL over the traditional teaching methods. Similar studies were conducted by Wojeiech Pawlina et al ${ }^{[10]}$, POTU B. K et $\mathrm{al}^{[12]}$, Satheesha $\mathrm{N}^{[13]}$, Nayak $\mathrm{S}^{[14]}$ who derived a similar response from the participants.

The present study also recorded the comparison of CBL with the conventional teaching methodology. The students were assessed after being taught by CBL and it was found that the tutelage helped the students to the hilt. In the first session out of 10 , students taught by CBL scored a mean of 6.46 marks while those taught by conventional method scored only 4.3 marks. The same was proved in the $2^{\text {nd }}$ session where in the students taught by CBL scored 9.41 marks out of 10 while those taught by traditional methods scored only 8.15 marks. There was a great difference in the mean marks scored in $1^{\text {st }}$ and $2^{\text {nd }}$ session, which was due to different methods used for assessment. In the first session students were assessed by long answer type question while in the second session students were assessed by the multiple type 
questions. A comparison was made by Mantosh chakraborty et $\mathrm{al}^{11}$ about CBL and PBL wherein he concluded that CBL had an edge over conventional method and over PBL also. The effectiveness of CBL in health education was also showed by Jill Elizabeth et al in $2012^{[12]}$.

There is no perfect method for teaching medical students, but their definitely is a need to reform the conventional method of medical education system. Although CBL seems to be more tedious and time consuming, it demands more dedication on part of teacher and students it is definitely an emerging trend especially for our medical colleges. The traditional mind set pattern of the faculty also needs to be changed before implementing CBL. Although there are many hurdles in the way of implementing CBL, but if $\mathrm{CBL}$ is implemented along with other teaching methods quality of our medical graduates will definitely go skywards.

\section{Conclusion}

Thus to conclude CBL is a very good approach which promotes student centered, clinically oriented learning. It leads to integration of basic and clinical sciences. CBL can definitely be used to make a dry subject like anatomy interesting for the students. Thus CBL used along with other traditional teaching methods can definitely help to improve our medical graduates.

\section{Implication}

Our basic motive of introducing CBL and comparing its effectiveness with other conventional teaching methods was achieved.

\section{References}

1. Praveen R Singh, Raksha Bhatt. Introduction of case based learning for teaching anatomy in a conventional medical school.
J.Anat.Soc. India 60(2) 232-235(2011).

2. Albanese MA, Mitchell S. Problem-based learning: a review of literature on its outcomes and implementation issues. Acad Med 1993;68:52-81.

3. Des Marchais JE, Bureau MA, Dumais B, Pigeon G. From traditional to problem-based learning: a case report of complete curriculum reform. Med Educ 1992;26"190-199.

4. Berkson L. Problem-based learning: Have the expectations been met? Acad Med 1993;68:S79-88.

5. Barrows HS. A traxomony of problem-based learning concepts. Med Educ. 1986;20:481-486.

6. Maudsley G. Do we all mean the same thing by problem-based learning? A review of the concepts and formulation of the ground rules. Acad Med. 1999;74:178-185.

7. Slavin SJ, Wilkes MS, Usatine R. Doctoring III. Innovations in education in the clinical years. Acad Med. 1995;70:1091-1095

8. Dolmans D, Schmidt H. The advantages of problem based curricula. Postgrad med J 1996:72:535 538.

9. Vernon D, Blake .R. Does problem based learning work? A meta analysis of evaluative research. Academic medicine 1993; 7:550 563.

10. Pawlina W, Romrell LJ, Rarey KE, Larkin L .H. problem based learning with gross anatomy specimens: one year trial. Clinical Anatomy 2005;4(4):298 306.

11. Chakraborty M, Gouroju S, Garg P. CBL in medical education effective learning methodology than PBL. Int J Intg Med Sci 2015;2(8):145 - 50 .

12. Elizabeth. J, Davies. D. The effectiveness of case based learning in health professional education. A BEME systematic review: BEME Guide No. 23.

13. Potu B. K, Shwe W. H, Jagadeesan S, Aung T, Cheng P. S. Scope of anatomy teaching in problem-based learning (PBL) sessions of integrated medical curriculum. Int. J. Morphology, 31(3):899-901, 2013.

14. Satheesha N, Komattil R, Nagabhooshana S, Kuvady LB. Teaching anatomy in a problem based learning (PBL) curriculum. Neuroanatomy 2006; 5: 23.

15. Nayak, S; Ramnarayan, K; Somayaji N. \& Bairy K. L. Teaching anatomy in a problem-based learning (PBL) curriculum. Neuroanatomy, 5:2-3, 2006.

Copyright: ( $)$ the author(s), publisher. Academia Anatomica International is an Official Publication of "Society for Health Care \& Research Development". It is an open-access article distributed under the terms of the Creative Commons Attribution Non-Commercial License, which permits unrestricted non-commercial use, distribution, and reproduction in any medium, provided the original work is properly cited.

How to cite this article: Nair SK, Rai N. Comparing the Effectiveness of Case Based Learning with Conventional Teaching in Anatomy. Acad. Anat. Int. 2019;5(2):34-36.

DOI: dx.doi.org/10.21276/aanat.2019.5.2.10

Source of Support: Nil, Conflict of Interest: None declared. 